\title{
Coastal sand dune vegetation of Velika plaža (Montenegro)
}

\author{
Danijela Stešević́ ${ }^{1}$, Filip Küzmič², Đorđije Milanovićs ${ }^{3}$, Milica Stanišić-Vujačić ${ }^{1}$, Urban Šilc ${ }^{2 *}$ \\ ${ }^{1}$ Faculty of Natural Sciences and Mathematics, University of Montenegro, Džordža Vašingtona bb, 81000 Podgorica, \\ Montenegro \\ ${ }^{2}$ Research Centre of the Slovenian Academy of Sciences and Arts, Institute of Biology, Novi Trg 2, 1000 Ljubljana, \\ Slovenia \\ ${ }^{3}$ Faculty of Forestry, University of Banja Luka, S. Stepanovića 75a, 78000 Banja Luka, Bosnia and Herzegovina
}

\begin{abstract}
Velika plaža (Ulcinj, Montenegro) is the largest sandy beach along the coast of the eastern Adriatic that still has well-developed sand-dune vegetation. Although the characterization of the flora and vegetation of Velika plaža has been addressed by many authors, knowledge on its vegetation remained poor. We made a phytosociological study of sandy beach vegetation comprising both dunal and wetland areas to provide a comprehensive survey of sand dune vegetation and habitat typology of Velika plaža. Based on 149 relevés (both from literature and recent field work), and with numerical classification (Flexible beta) and ordination (Non-metric multidimensional scaling) our results show that the vegetation of Velika plaža is much more diverse than previously known. Altogether, 19 plant communities from 6 vegetation classes were identified. Among them we described two new associations: Cuscuto cesatianae-Phyletum nodiflorae and Onobrychido caput-galli-Vulpietum fasciculatae.
\end{abstract}

Keywords: classification, endangered, habitat types, plant communities, psammophytic, sandy beach, syntaxonomy

\section{Introduction}

Sand dunes are one of the most extreme ecosystems due to abiotic environmental factors, and among the most endangered, due to various kinds of human impact (Maun 2009). These two factors account for the high research interest of the remaining sandy beaches and their biota.

Thirty coastal habitats are included in the European Red list of habitats as they are experiencing decline in extent and quality (Janssen et al. 2016). In fact it is estimated that about $70 \%$ of dune ecosystems of European coasts were lost during the last century due to urbanization (Brown and McLachlan 2002).

Velika plaža (Fig. 1) is the largest sandy beach along the eastern Adriatic coast with still well-developed vegetation. Coasts along the NE Adriatic are mainly rocky and steep (see Šilc et al. 2016a), and anthropogenic impact on many sandy beaches has destroyed or depauperated the vegetation, so that in some locations (Nin and Velika Saplunara, Croatia) only fragments are still developed. Surveys of sand dune vegetation (Marcenò et al. 2018, Šilc et al. 2016a) show gaps of vegetation data along the eastern Adriatic coast and our study contributes to filling them.

Characterization of flora and vegetation of Velika plaža have been researched by many authors (Bubanja 2016, Bubanja et al. 2019, and references therein). Recently several studies for different purposes were conducted to present the impact of alien species (Stešević et al. 2017a, Šilc et al. 2019), trampling (Šilc et al. 2017), and litter on vegetation (Šilc et al. 2018) as well as human impact in general (Šilc et al. 2016b), but a complete overview of vegetation communities has never been made. According to several authors (Trinajstić 1989a, Mijović 1994, Mijović et al. 2006, 2012,) only two plant communities were reported for Velika plaža: Cakilo-Xanthietum italici and Euphorbio paraliae-Agropyretum junceiformis; however, recent studies (Šilc et al. 2019, Stešević et al. 2017b) have suggested that the vegetation of Velika plaža is much more diverse.

The aim of our study was to make a comprehensive survey of sand dune vegetation of the largest sand beach system in Eastern Adriatic with own field work and literature data,

\footnotetext{
* Corresponding author e-mail: urban@zrc-sazu.si
} 
and to present our results also in the view of habitat typology of Habitat Directive (European Communities Council 1992).

\section{Materials and methods}

\section{Study area}

Velika plaža in Ulcinj (Montenegro) is considered to be the northernmost and longest beach on the eastern Adriatic coast (ca. $12 \mathrm{~km}$ ), with still well preserved sand dune vegetation. Since 1968, the beach has been recognized as a monument of nature (Official Gazette of the Socialist Republic of Montenegro, SRCG 30/68). According to the Spatial Plan of Special Purpose for the Coastal Zone, one spatial unit on the east side of Velika plaža is recognized as a newly protected nature reserve, with

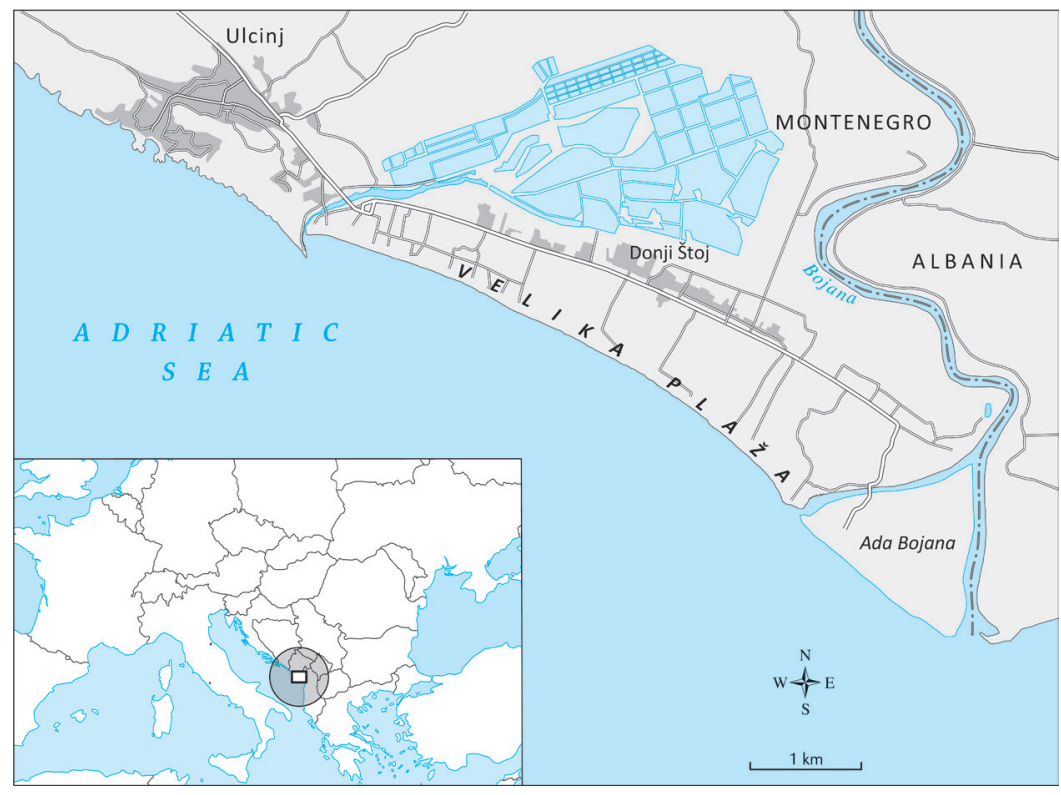

Fig. 1. Sandy beach Velika plaža in Montenegro. forests, marshes and meadows. The area is protected from trampling or grazing with a wooden fence (JPMD 2015). However, the rest of the beach, which represents more than $75 \%$ of the natural coast and $97 \%$ of whole sand dune system, is heavily impacted by tourism, illegal dumping, sand extraction and urbanization (Petrović and Karaman 2009). Eleven NATURA 2000 habitats are reported for the beach and its hinterland: Annual vegetation of drift lines (1210), Embryonic shifting dunes (2110), Shifting dunes along the shoreline with Ammophila arenaria (white dunes, 2120), Fixed coastal dunes with herbaceous vegetation (grey dunes, 2130*), Humid dune slacks (2190), Dunes with Euphorbia terracina (2220), Mediterranean salt meadows (Juncetalia maritimae) (1410), Brachypodietalia dune grasslands with annuals (2240), Wooded dunes with Pinus pinea and/or Pinus pinaster $\left(2270^{\star}\right)$, Mediterranean temporary ponds (3170), and Salix alba and Populus alba galleries (92A0) (Petrović et al. 2012). The site is included in the list of IPA areas (Petrović and Karaman 2009).

\section{Sampling and data analysis}

In the period of 2012-2019 we recorded 93 relevés of all the vegetation types found on the sand dune system according to the standard Central European method (Braun-Blanquet 1964, van der Maarel 2005). The new relevés made on sand dunes (On-line Suppl. Tabs. 1 and 2) and some from the literature (Trinajstić 1989a, Mijović 1994, Mijović et al. 2006, 2012,) were entered into the Turboveg 2 database (Hennekens and Schaminée 2001).

For the first step, numerical classification, we used a larger (149 original and published relevés) and a smaller (93 original relevés) dataset to find out the general structure. As both analyses revealed similar pattern, for further numerical analysis we used only the original relevés as those from the literature had large plot sizes, were not made for syntaxonomical study or were frequently transitional. Nevertheless we used them in ordination analysis of whole dataset.
Numerical classification (Flexible beta $(\beta=-0.25)$ and Relative Sørensen) was performed on the 93 original relevés. Some of the transitional relevés were later classified according to expert knowledge. Diagnostic species for the plant communities were determined in the JUICE program (Tichý 2002) by their fidelity values (Chytrý et al. 2002). The size of all groups was standardized to equal sizes (Tichý and Chytrý 2006), and the Fisher's exact test $(P<0.05)$ was applied. Species with Phi-coefficient values higher than 0.20 were considered as diagnostic.

Unweighted average ecological indicator values (Pignatti et al. 2005) of relevés were passively projected onto a non-metric multidimensional scaling (NMDS) biplot (Bray-Curtis distance measure used) to show ecological relationship among these relevés and to explain environmental gradients underlying the main ordination axes. Log transformed cover data were used as the input data and all 149 relevés were used in this analysis. Analysis was performed in program $\mathrm{R}$ ( $\mathrm{R}$ Development Core Team 2012) using the vegan package in the JUICE program (Tichý 2002).

The nomenclature of taxa follows Euro+Med (2006). Syntaxonomical concepts and nomenclature of higher syntaxa follow Mucina et al. (2016). For the crosswalk between vegetation syntaxa and habitat types, we refer to the Catalogue of habitat types of Montenegro important for the Europe (Petrović et al. 2012).

\section{Results}

We compiled a set of 149 relevés (93 original) and identified 19 plant communities classified into six vegetation classes. They are presented in the syntaxonomical scheme and described in brief. The first classification, using the whole dataset of 149 relevés (not shown), identified two main clusters separating sand dune and wetland vegetation on the sandy beach. In the next step we classified each of these two clusters separately (Figs. 2, 3). 
Tab. 1. Shortened synoptic table of studied syntaxa. Diagnostic species with fidelity index phi higher than 0.20 are presented. Columns: $1-$ Juncetum maritimo-acuti, 2 - Limonio narbonensis-Juncetum gerardii, 3 - Cuscuto cesatianae-Phyletum nodiflorae, 4 - Eriantho-Schoenetum nigricantis, 5 - Holoschoenetum romani, 6 - Cakilo-Xanthietum strumarii, 7 -Euphorbio paraliae-Agropyretum junceiformis, 8 - Medicagini marinae-Ammophiletum australis, 9 - Cutandia maritima community, 10 - Euphorbio terracinae-Silenetum nicaeensis, 11 - Onobrychido caput-galli-Vulpietum fasciculatae, 12 - Scirpetum maritimo-litoralis, 13 - Phragmitetum communis, 14 - Typhetum angustifoliae, 15 - Scirpetum lacustris, 16 - Cladietum marisci, 17 - Cyperetum longi, 18 - Cyperetum flavescentis, 19 - Cypero-Paspaletum distichi.

\begin{tabular}{|c|c|c|c|c|c|c|c|c|c|c|c|c|c|c|c|c|c|c|c|}
\hline Column & 1 & 2 & 3 & 4 & 5 & 6 & 7 & 8 & 9 & 10 & 11 & 12 & 13 & 14 & 15 & 16 & 17 & 18 & 19 \\
\hline Number of relevés & 4 & 2 & 12 & 7 & 4 & 8 & 7 & 6 & 5 & 7 & 7 & 7 & 4 & 1 & 1 & 7 & 1 & 1 & 2 \\
\hline Juncus maritimus & 57.6 & --- & --- & 25.6 & 3.5 & --- & --- & --- & $\begin{array}{ll}-- \\
\end{array}$ & --- & --- & --- & --- & --- & --- & --- & --- & --- & $\begin{array}{ll}-- \\
\end{array}$ \\
\hline Juncus acutus & 42 & --- & --- & -- & --- & --- & --- & --- & --- & --- & --- & --- & --- & --- & --- & --- & --- & --- & --- \\
\hline Juncus gerardi & --- & 83.4 & --- & --- & 3 & --- & --- & --- & --- & --- & --- & --- & --- & --- & --- & --- & --- & --- & --- \\
\hline Phyla nodiflora & --- & --- & 49 & --- & --- & --- & --- & --- & --- & --- & --- & 12.5 & --- & --- & --- & --- & --- & --- & --- \\
\hline Cuscuta australis ssp. cesatiana & --- & --- & 43 & --- & --- & --- & --- & --- & --- & --- & --- & --- & --- & --- & --- & --- & --- & --- & --- \\
\hline Centaurium spicatum & --- & --- & 21.7 & --- & --- & --- & --- & --- & --- & --- & --- & --- & --- & --- & --- & --- & --- & --- & --- \\
\hline Polypogon maritimus & --- & --- & 24.7 & --- & --- & --- & --- & --- & --- & --- & --- & --- & --- & --- & --- & --- & --- & --- & --- \\
\hline Bidens frondosus & --- & --- & 24.2 & --- & --- & --- & --- & --- & --- & --- & --- & --- & --- & --- & --- & --- & --- & --- & --- \\
\hline Schoenus nigricans & --- & --- & --- & 74.5 & --- & --- & --- & --- & --- & --- & --- & --- & --- & --- & --- & --- & --- & --- & --- \\
\hline Tripidium ravennae & --- & --- & --- & 75.2 & --- & --- & --- & --- & --- & --- & --- & --- & --- & --- & --- & --- & --- & --- & --- \\
\hline Rubus ulmifolius & --- & --- & --- & 28.5 & --- & --- & --- & --- & --- & --- &.-- & --- & --- & --- & --- &.-- & --- & --- & --- \\
\hline Linum bienne & --- & --- & --- & 24.5 & --- & --- & --- & --- & --- & --- & --- & --- & --- & --- & --- & --- & --- & --- & --- \\
\hline Serapias vomeracea & --- & --- & --- & 20.7 & --- & --- & --- & --- & --- & --- & --- & --- & --- & --- & --- & --- & --- & --- & --- \\
\hline Scirpoides holoschoenus & --- & --- & 22.3 & 7.8 & 30.3 & --- & --- & --- & --- & --- & --- & --- & --- & --- & --- & --- & --- & --- & --- \\
\hline Carex distans & --- & --- & --- & --- & 20.3 & --- & --- & --- & --- & --- & --- & --- & --- & --- & --- & --- & --- & --- & --- \\
\hline Lysimachia vulgaris & --- & --- & --- & --- & 20.3 & --- & --- & --- & --- & --- & --- & --- & --- & --- & --- & --- & --- & --- & --- \\
\hline Xanthium orientale ssp. italicum & --- & --- & 11.7 & --- & -- & 12.2 & --- & --- & --- & --- & --- & --- & --- & -.- & --- & --- & --- & --- & --- \\
\hline Cakile maritima & --- & --- & --- & --- & --- & 17.7 & 10.3 & --- & --- & --- & --- & --- & --- & --- & --- & --- & --- & --- & --- \\
\hline Salsola kali & --- & --- & --- & --- & --- & 18.2 & --- & --- & 23.8 & --- & --- & --- & --- & --- & --- & --- & --- & --- & --- \\
\hline Cyperus capitatus & --- & --- & --- & --- & --- & --- & 35.3 & 19.6 & -- & --- & --- & --- & --- & --- & --- & --- & --- & --- & --- \\
\hline Echinophora spinosa & --- & --- & --- & --- & --- & 12 & 29.9 & 13.6 & --- & --- & --- & --- & --- & --- & --- & --- & --- & --- & --- \\
\hline Eryngium maritimum & --- & --- & --- & --- & --- & 11 & 29 & 13.6 & --- & --- & --- & --- & --- & --- & --- & --- & --- & --- & --- \\
\hline Pancratium maritimum & --- & --- & --- & --- & --- & -- & 22.7 & -- & 7.1 & --- & 9.7 & --- & --- & --- & --- & --- & -- & --- & --- \\
\hline Equisetum ramosissimum & --- & --- & --- & --- & --- & --- & 26.5 & --- & --- & --- & --- & --- & --- & --- & --- & --- & --- & --- & --- \\
\hline Anisantha madritensis & --- & --- & --- & --- & --- & --- & 24.6 & --- & --- & --- & --- & --- & --- & --- & --- & --- & -- & --- & --- \\
\hline Ammophila arenaria & --- & --- & -- & --- & --- & --- & --- & 66.8 & --- & --- & --- & --- & --- & --- & --- & --- & -- & --- & --- \\
\hline Cutandia maritima & --- & --- & --- & --- & --- & --- & --- & --- & 57 & --- & --- & --- & --- & --- & --- & --- & --- & --- & --- \\
\hline Phleum arenarium & --- & --- & --- & --- & --- & --- & --- & --- & 40.8 & --- & --- & --- & --- & --- & --- & --- & --- & --- & --- \\
\hline Anisantha sterilis & --- & --- & --- & --- & --- & --- & --- & --- & 23 & --- & 21.8 & --- & --- & --- & --- & --- & --- & --- & --- \\
\hline Medicago littoralis & --- & --- & --- & --- & --- & --- & --- & 9.7 & 20.5 & 10.2 & 11.6 & --- & --- & --- & --- & --- & --- & --- & --- \\
\hline Calystegia soldanella & --- & --- & -- & --- & --- & --- & --- & 8.6 & 20.3 & --- & --- & --- & --- & --- & --- & --- & --- & --- & --- \\
\hline Euphorbia terracina & --- & --- & --- & --- & --- & --- & --- & --- & -- & 57.3 & --- & --- & --- & --- & --- & --- & --- & --- & --- \\
\hline Artemisia campestris & --- & --- & --- & --- & --- & --- & 9.5 & --- & --- & 40.6 & --- & --- & --- & --- & --- & --- & --- & --- & -- \\
\hline Medicago marina & --- & --- & --- & --- & --- & --- & 12.1 & --- & 7.4 & 42.6 & --- & --- & --- & -.- & --- & --- & --- & --- & --- \\
\hline Vulpia fasciculata & --- & --- & --- & --- & --- & --- & --- & 3 & --- & 39.3 & 47.2 & --- & --- & --- & --- & --- & --- & --- & --- \\
\hline Alkanna tinctoria & --- & --- & --- & --- & --- & --- & --- & --- & --- & 33.3 & 27.8 & --- & --- & --- & --- & --- & --- & --- & --- \\
\hline Hedypnois rhagadioloides & --- & --- & --- & --- & --- & --- & --- & --- & --- & 25.5 & --- & --- & --- & --- & --- & --- & --- & --- & --- \\
\hline Valerianella sp. & --- & --- & --- & --- & --- & --- & --- & --- & --- & 20.7 & --- & --- & --- & --- & --- & --- & --- & --- & --- \\
\hline Onobrychis caput-galli & --- & --- & --- & --- & --- & --- & --- & --- & 5.3 & --- & 70.6 & --- & --- & --- & --- & --- & --- & --- & --- \\
\hline Hypochaeris glabra & --- & --- & -- & --- & --- & --- & --- & -- & -- & --- & 30.9 & --- & --- & --- & --- & --- & -- & --- & --- \\
\hline Lagurus ovatus & --- & --- & --- & --- & --- & --- & 9.7 & --- & --- & --- & 28 & --- & --- & --- & --- & --- & --- & --- & --- \\
\hline Typha latifolia & --- & --- & --- & --- & --- & --- & --- & --- & --- & --- & 24.9 & --- & --- & --- & --- & --- & --- & --- & --- \\
\hline Dasypyrum villosum & --- & --- & --- & --- & --- & --- & --- & --- & --- & --- & 20.7 & --- & --- & --- & --- & --- & --- & --- & --- \\
\hline Bolboschoenus maritimus & --- & 4.6 & --- & --- & --- & --- & --- & --- & --- & --- & --- & 48.1 & --- & --- & --- & --- & --- & --- & --- \\
\hline Juncus compressus & --- & --- & --- & --- & --- & --- & --- & -- & --- & --- & --- & 22.1 & --- & --- & --- & --- & -- & --- & --- \\
\hline Phragmites australis & --- & --- & -- & --- & --- & --- & --- & -- & --- & --- & --- & -- & 62.8 & --- & --- & --- & --- & --- & --- \\
\hline Baldellia ranunculoides & --- & --- & --- & --- & --- & --- & --- & --- & --- & --- & --- & --- & 21 & --- & --- & --- & --- & --- & --- \\
\hline Nymphaea alba & --- & --- & -- & --- & --- & --- & --- & --- & --- & --- & --- & --- & 20.3 & --- & --- & --- & -- & --- & --- \\
\hline Butomus umbellatus & --- & --- & --- & --- & --- & --- & --- & --- & --- & --- & --- & --- & 29.3 & --- & --- & --- & --- & --- & --- \\
\hline Schoenoplectus lacustris ssp. glaucus & --- & --- & --- & --- & --- & --- & --- & -- & --- & --- & --- & --- & --- & 31.6 & --- & --- & --- & --- & --- \\
\hline Potamogeton lucens & --- & --- & --- & --- & --- & --- & --- & --- & --- & --- & --- & --- & --- & 26 & 20.6 & --- & --- & --- & --- \\
\hline Utricularia vulgaris & --- & --- & --- & --- & --- & --- & --- & --- & --- & --- & --- & --- & --- & 27.3 & 27.3 & --- & --- & --- & --- \\
\hline Schoenoplectus litoralis & --- & --- & --- & --- & --- & --- & --- & --- & --- & --- & --- & 11.6 & --- & --- & 68.6 & --- & --- & --- & --- \\
\hline Cladium mariscus & --- & --- & --- & --- & --- & --- & --- & --- & --- & --- & --- & -- & --- & --- & --- & 86.7 & --- & --- & --- \\
\hline Gratiola officinalis & --- & --- & --- & --- & --- & --- & --- & --- & --- & --- & --- & --- & --- & --- & --- & 20.4 & --- & --- & --- \\
\hline Cyperus longus & --- & --- & --- & --- & --- & --- & --- & --- & --- & --- & --- & --- & --- & --- & --- & --- & 96.7 & --- & --- \\
\hline Potentilla reptans & --- & --- & --- & --- & --- & --- & --- & --- & --- & --- & --- & --- & --- & --- & --- & --- & 52.6 & --- & --- \\
\hline Oenanthe pimpinelloides & --- & --- & 3.8 & --- & --- & --- & --- & --- & --- & --- & --- & --- & --- & --- & --- & --- & 33.7 & --- & --- \\
\hline Poa trivialis & --- & --- & --- & 7.5 & --- & --- & --- & --- & --- & --- & --- & --- & --- & --- & --- & --- & 31.9 & --- & --- \\
\hline Calystegia sepium & --- & --- & --- & -- & --- & --- & --- & --- & --- & --- & --- & --- & --- & --- & --- & --- & 52.2 & --- & --- \\
\hline Rumex conglomeratus & --- & --- & --- & --- & --- & --- & --- & --- & --- & --- & --- & --- & --- & --- & --- & --- & 35.1 & --- & --- \\
\hline Vicia villosa ssp. varia & --- & --- & --- & --- & --- & --- & --- & --- & --- & --- & --- & --- & --- & --- & --- & --- & 36.7 & --- & --- \\
\hline Verbena officinalis & --- & --- & --- & -- & --- & --- & --- & -- & --- & --- & --- & --- & --- & --- & --- & --- & 32.4 & --- & --- \\
\hline Carex hirta & --- & --- & --- & --- & --- & --- & --- & --- & --- & --- & --- & --- & --- & --- & --- & --- & 40.7 & --- & --- \\
\hline Holcus lanatus & --- & --- & --- & --- & --- & --- & --- & --- & --- & --- & --- & --- & --- & --- & --- & --- & 40.7 & --- & --- \\
\hline Daucus carota & --- & --- & --- & --- & --- & --- & --- & --- & --- & --- & --- & --- & --- & --- & --- & --- & 36.7 & --- & --- \\
\hline Quercus robur & --- & --- & --- & -- & --- & --- & --- & -- & --- & --- & --- & --- & --- & --- & --- & --- & 36.7 & --- & --- \\
\hline Crepis vesicaria & --- & --- & --- & -- & --- & --- & --- & -- & --- & --- & --- & --- & --- & --- & --- & --- & 36.7 & --- & --- \\
\hline Cyperus flavescens & --- & --- & --- & --- & --- & --- & --- & --- & --- & --- & --- & --- & --- & --- & --- & --- & --- & 90.4 & --- \\
\hline Plantago major ssp. intermedia & --- & --- & --- & --- & --- & --- & --- & --- & --- & --- & --- & 8 & --- & --- & --- & --- & --- & 30.4 & --- \\
\hline Paspalum distichum & --- & --- & 1.8 & --- & --- & --- & --- & -- & --- & --- & --- & -- & --- & --- & --- & --- & --- & --- & 85.6 \\
\hline Paspalum dilatatum & --- & --- & --- & --- & --- & --- & --- & --- & --- & --- & --- & --- & --- & --- & --- & --- & --- & --- & 38.8 \\
\hline
\end{tabular}




\section{Syntaxonomical scheme}

Juncetea maritimi Br.-Bl. in Br.-Bl. et al. 1952

Juncetalia maritimi Br.-Bl. ex Horvatić 1934

Juncion maritimi Br.-Bl. ex Horvatić 1934

Juncetum maritimo-acuti Horvatić 1934

Cuscuto cesatianae-Phyletum nodiflorae ass. nova hoc loco

Holotypus: Tab. 2, relevé no. 10

Limonio narbonensis-Juncetum gerardii Géhu et Biondi 1994

Agropyro-Plantaginion maritimi Horvatić 1934

Holoschoenetum romani Tchou 1948

Cakiletea maritimae Tx. et Preising ex Br.-Bl. et Tx. 1952

Thero-Atriplicetalia Pignatti 1953

Euphorbion peplidis Tx. ex Oberd. 1952

Cakilo-Xanthietum strumarii (Beg. 1941) Pignatti 1958 (syn. Xanthio-Cakiletum maritimae,

Salsolo kali-Cakiletum maritimae Costa et Manz. corr. Riv.-Mart. et al. 1992)

Ammophiletea Br.-Bl. et Tx. ex Westhoff et al. 1946

Ammophiletalia Br.-Bl. et Tüxen ex Westhoff et al. 1946

Ammophilion Br.-Bl. 1921

Euphorbio paraliae-Agropyretum junceiformis Tüxen in Br.-Bl. et Tüxen 1952 corr. Darimont, Duvigneaud et Lambinon 1962 (syn. Sporobolo-Elymetum farcti (Gehu et al.) Gehu 1984, Agropyretum mediterraneum (Kuhn.) Br.-Bl. 1933, Echinophoro-Elymetum farcti Gehu 1988, Eryngio-Cyperetum capitati Dmitar Lakušić nom.nud. 2011)

Medicagini marinae-Ammophiletum australis Br.-Bl. 1921 corr. F. Prieto et T.E. Díaz 1991 (syn. Ammophiletum australis R. Lakušić 1965 inedit)

Cutandia maritima community

Isoëto-Nanojuncetea Br.-Bl. et Tx. in Br.-Bl. et al. 1952

Nanocyperetalia Klika 1935

Nanocyperion Koch 1926

Cyperetum flavescentis W.Koch ex Aichinger 1933

Verbenion supinae Slavnić 1951

Cypero-Paspaletum distichi Horvatić 1954

Phragmito-Magnocaricetea Klika in Klika et Novák 1941

Bolboschoenetalia maritimi Hejny in Holub et al. 1967

Scirpion maritimi Dahl et Hadač 1941

Scirpetum maritimo-litoralis (Br.-Bl. in Br.-Bl., Roussine et Nègre 1952) O. de Bolòs 1962

Phragmitetalia Koch 1926

Phragmition communis Koch 1926

Phragmitetum communis Savič 1926

Typhetum angustifoliae Soo 1927

Scirpetum lacustris Chouard 1924

Saccharetalia ravennae Biondi, Blasi et Casavecchia in Biondi et al. 2014

Imperato cylindricae-Saccharion ravennae Br.-Bl. et O. de Bolos 1958

Eriantho-Schoenetum nigricantis (Pignatti 1953) Géhu in Géhu et al. 1984

Magnocaricetalia Pignatti 1953

Magnocaricion elatae Koch 1926

Cladietum marisci Allorge 1921

Cyperetum longi Micevski 1957

Helianthemetea guttati Rivas Goday et Rivas-Mart. 1963

Vulpietalia Pignatti 1953 (syn. Cutandietalia)

Laguro-Vulpion fasciculatae Géhu et Biondi 1994

Euphorbio terracinae-Silenetum nicaeensis Lavrentiades 1964

Onobrychido caput-galli-Vulpietum fasciculatae ass. nova hoc loco

Holotypus: Tab. 3, relevé no. 3 


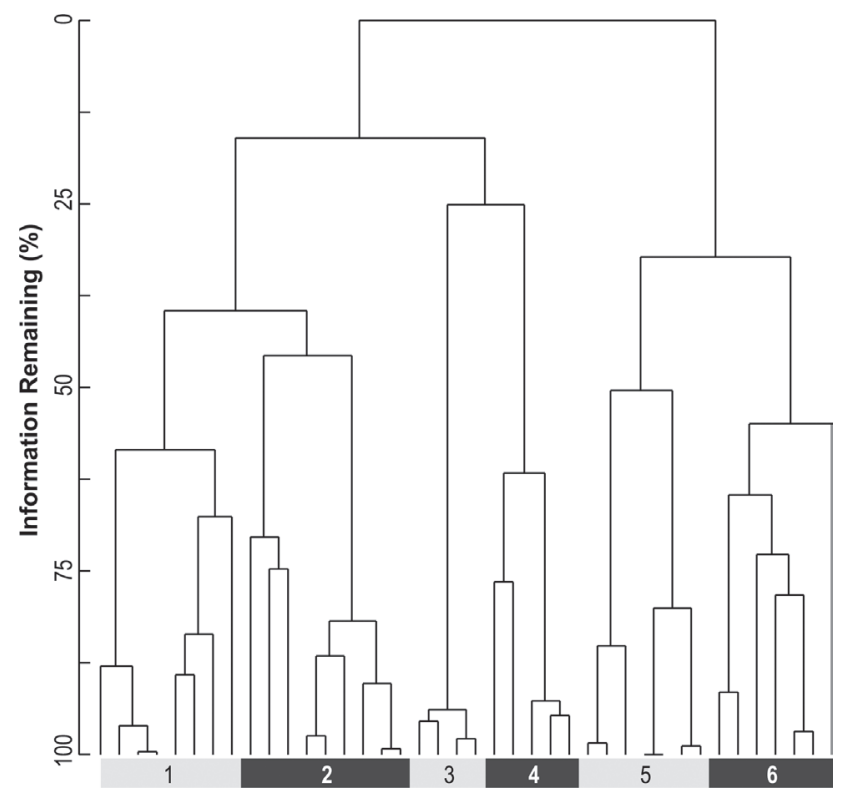

Fig. 2. Classification of sand dune vegetation of Velika plaža. Clusters: 1 - Cakilo-Xanthietum strumarii, 2 - Euphorbio paraliaeAgropyretum junceiformis, 3 - Cutandia maritima community, 4 - Medicagini marinae-Ammophiletum australis, 5 - Euphorbio terracinae-Silenetum nicaeensis, 6 - Onobrychido caput-galli-Vulpietum fasciculatae.

Diagnostic species obtained by fidelity coefficient can only be considered as local because of the limited study area and many transitional stands (Tab. 1). Diagnostic species contain both differential and character species, some of which can be diagnostic for two plant communities.

\section{Salt marshes}

Juncetum maritimo-acuti is dominated by tall rushes (Juncus maritimus and J. acutus) and forms large stands in Velika plaža. It thrives in the back of the dunes on sand-silty substrate and is periodically flooded. Scirpetum maritimo-litoralis is a community dominated by Bolboschoenus maritimus, which occupies flooded areas with brackish water.

Cuscuto cesatianae-Phyletum nodiflorae ass. nova is found in flooded depressions on sand dunes that develop between higher parts of the dunes or behind them or along smaller streams of sub-saline water, additionally sometimes also on heavily trampled surfaces (Tab. 2). The soil is often silty and becomes compacted during summer droughts. The diagnostic species is Cuscuta australis ssp. cesatiana, known as a frequent inhabitant of sandy habitats, parasitizing on Polygonum maritimum, Xanthium orientale ssp. italicum and other psammopyhtes (Pignatti 1982). Limonio narbonensis-Juncetum gerardii is a helophytic community that thrives in stagnant brackish water that dries out during summer. Stands are species poor, dominated by Juncus gerardi. Holoschoenetum romani thrives in depressions most commonly in the backdunes. These are the lowest sites in the dune system and are flooded for the longest period of time.

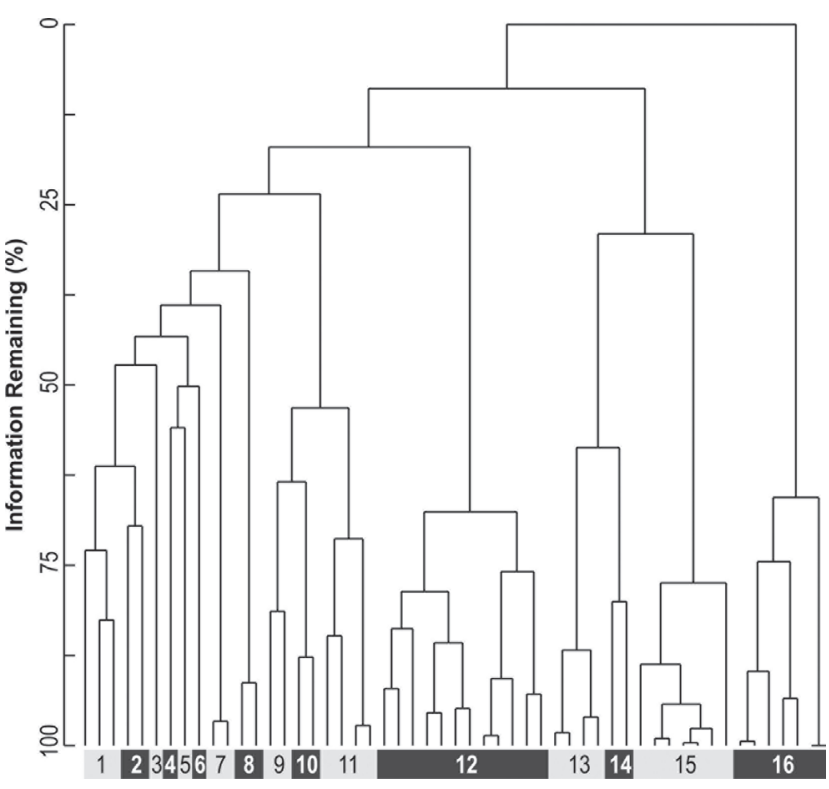

Fig. 3. Classification of wetland vegetation of Velika plaža. Clusters: 1 - Juncetum maritimo-acuti, 2-4 - Holoschoenetum romani, 5 - Cyperetum flavescentis, 6 - Cyperetum longi, 7 -Limonio narbonensisJuncetum gerardii, 8 - Cypero-Paspaletum distichi, 9-11 - Scirpetum maritimo-litoralis, 12 - Cuscuto cesatianae-Phyletum nodiflorae, 13 - Phragmitetum communis, 14 - Typhetum angustifoliae and Scirpetum lacustris, 15 - Cladietum marisci, 16 - Eriantho-Schoenetum nigricantis.

\section{Sand dunes}

Cakilo-Xanthietum strumarii is found on the sand deposition zone, the first part of the beach following the aphytic zone. It is a species poor community, strongly influenced by sea waves, intense sand movement and salt water spraying. It occupies the nutrient rich drift line. The association is characterized by the presence of an alien species Xanthium orientale subsp. italicum, which is very abundant on Velika plaža in the first and the second vegetation zone.

The following plant communities on the sand dunes in the sea-inland zonation are still subjected to strong wind, waves, salt spray, and drought. Embryonic dunes are occupied by the stands of Euphorbio paraliae-Agropyretum junceiformis. This vegetation type is very common on Velika plaža and occupies flat, low sand dunes. In general sand dunes on Velika plaža are low compared to those in Albania or Italy. The next community in the zonation is the Medicagini marinae-Ammophiletum australis, where Elytrigia juncea is replaced by Ammophila arenaria, which further stabilizes the sand and makes these shifting dunes higher than the embryonic dunes. Ammophila arenaria stands are small and patchy on Velika plaža, forming loosely connected "dune islands" with steeper slopes. Wind and water erosion are more pronounced and the development of these stands is a result of micro topography and edaphic conditions and they are rare on Velika plaža. On the other hand embryonic, semi-fixed and fixed dunes are syndynamically connected and represent successional series (Fig. 4). 


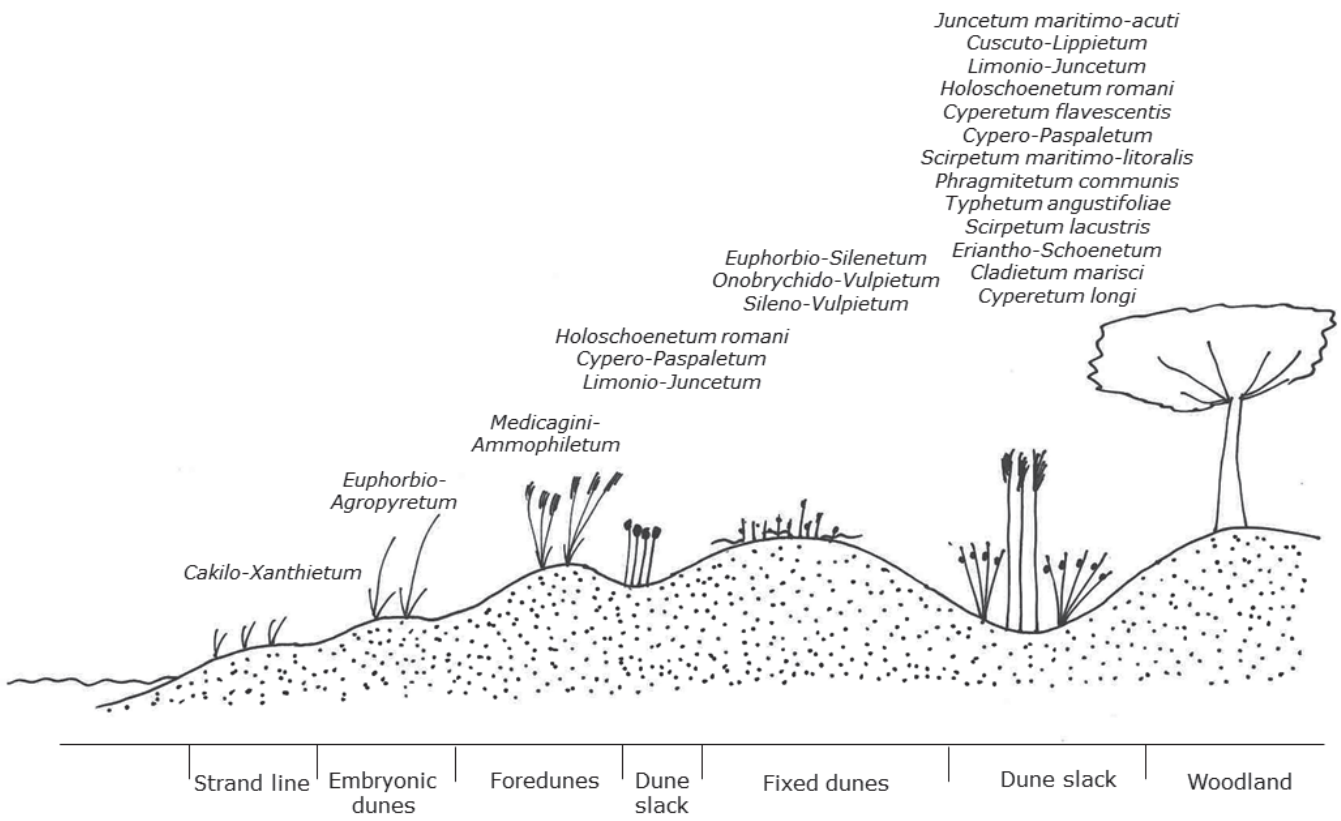

Fig. 4. Scheme of typical vegetation zonation on the sand beach Velika plaža.

Tab. 2. Phytosociological table of the Cuscuto cesatianae-Phyletum nodiflorae from Velika plaža (Ulcinj, Montenegro). ${ }^{*}$ - nomenclatural type.

Relevé number

Relevé number in On-line Suppl. Tab. 1

Relevé area $\left(\mathrm{m}^{2}\right)$

Cover herb layer (\%)

\begin{tabular}{cccccccccccc}
1 & 2 & 3 & 4 & 5 & 6 & 7 & 8 & 9 & $10^{*}$ & 11 & 12 \\
7 & 8 & 9 & 10 & 11 & 12 & 13 & 14 & 15 & 16 & 17 & 18 \\
4 & 4 & 4 & 4 & 4 & 4 & 4 & 4 & 4 & 4 & 4 & 2 \\
70 & 60 & 70 & 45 & 60 & 40 & 80 & 70 & 70 & 70 & 50 & 80 \\
\hline
\end{tabular}

Diagnostic species

Phyla nodiflora

Cuscuta australis subsp. cesatiana

Juncetea maritimi

Scirpoides holoschoenus

Juncus maritimus

Polypogon maritimus

Oenanthe pimpinelloides

Samolus valerandi

Phragmitetea

Phragmites australis

Typha angustifolia

Bolboschoenus maritimus

Ammophiletea

Tripolium pannonicum subsp. tripolium

Echinophora spinosa

Cynanchum acutum

Molinio-Arrhenatheretea

Mentha aquatica

Juncus articulatus

Lythrum salicaria

Lotus corniculatus

Gratiola officinalis

Juncus compressus

\section{Other species}

Xanthium orientale subsp. italicum

Bidens frondosus

Centaurium spicatum

Paspalum distichum

Dittrichia viscosa

Euphorbia maculata

Ranunculus sp.

Atriplex prostrata

Amorpha fruticosa

Salix alba

Lythrum hyssopifolia

Centaurium erythrea

\section{Species present only in one relevé:}

Tamarix dalmatica 1: +; Rumex conglomeratus 1: +; Hypochaeris radicata 2: +; Parapholis incurva 3: +; Vitex agnus-castus 4: +; Baldellia ranunculoides 4: +; Leontodon sp. 5: +; Persicaria maculosa 5: 1; Cynodon dactylon 7: 1; Medicago littoralis 8: +; Periploca graeca 9: +; Plantago major ssp. intermedia 9: +; Limbarda crithmoides 10: +; Populus alba 11: +. 
Semi-fixed dunes with Euphorbia terracina are found behind the embyonic shifting dunes and are the next stage in the succession. This asssociation can be placed floristically between Euphorbio-Agropyretum and Onobrychidi-Vulpietum, although it is more similar to the latter association. We classified it as Euphorbio terracinae-Silenetum nicaeensis.

Fixed dunes are the last in the zonation before the onset of woody vegetation. The most widespread community is the ass. nova dominated by Vulpia fasciculata and Onobrychis caput-galli, which are also the diagnostic species of the association (Tab. 3). Stands occupy the greatest part of sand dunes, which are predominantly flat, compared to the previous dune zones with consistent (even if small) slopes, and are in a mosaic with Ammophiletea communities. Grasslands have the most closed vegetation cover which becomes more open due to human impact. Fragmentarily, on stabilized dunes, there are also stands of Cutandia maritima, representing the first stages of development towards Onobrychido-Vulpietum. Typical sand dune vegetation is best preserved in the south-eastern part of the beach, which is so far less touristically developed.

\section{Dune slacks}

Among other sand dune communities a great diversity of usually monodominant plant communities appears in wet dune slacks and depressions. Their floristic composition depends on the salinity of the water and period of flooding.

Phragmitetum communis is dominated by Phragmites australis and is widely distributed in the area, mostly in the back of the dunes where fresh water is present for a longer period. Typhetum angustifoliae is present in patches within Phragmites australis stands or around ponds in the hinterland.

Scirpetum lacustris is found in brackish water and is connected to Phragmites stands but flooded for longer periods.

Eriantho-Schoenetum nigricantis stands are developed in the depressions between the dunes with Tripidium ravennae and Schoenus nigricans as edificators of community. The site is flooded by subsaline water. Cladietum marisci occupies large areas with Cladium mariscus as the dominant species. Cyperetum longi thrives on wet soils, often near channels and is dominated by the tall sedge Cyperus longus.

Tab. 3. Phytosociological table of the Onobrychido caput-galli-Vulpietum fasciculatae from Velika plaža (Ulcinj, Montenegro). ${ }^{\star}-$ nomenclatural type.

\begin{tabular}{|c|c|c|c|c|c|c|c|}
\hline Relevé number & 1 & 2 & $3^{*}$ & 4 & 5 & 6 & 7 \\
\hline Relevé number in On-line Suppl. Tab. 1 & 63 & 64 & 65 & 66 & 67 & 68 & 69 \\
\hline Relevé area $\left(\mathrm{m}^{2}\right)$ & 20 & 15 & 25 & 15 & 15 & 16 & 8 \\
\hline Cover herb layer (\%) & 70 & 80 & 100 & 60 & 80 & 85 & 80 \\
\hline \multicolumn{8}{|l|}{ Diagnostic species } \\
\hline Vulpia fasciculata & 3 & 2 & 5 & 3 & 3 & 3 & 2 \\
\hline Onobrychis caput-galli & 2 & 3 & 4 & 3 & 4 & 4 & 2 \\
\hline Alkanna tinctoria & 2 & + & 3 & . & 1 & . & 1 \\
\hline \multicolumn{8}{|l|}{ Helianthemetea guttati } \\
\hline Medicago littoralis & + & . & 3 & 1 & . & + & + \\
\hline Hypochaeris glabra & . & 1 & 2 & . & 1 & + & 1 \\
\hline Lagurus ovatus & . & . & + & 2 & + & + & 1 \\
\hline \multicolumn{8}{|l|}{ Ammophiletea } \\
\hline Pancratium maritimum & 1 & 2 & . & . & + & + & + \\
\hline Cyperus capitatus & 1 & 1 & . & . & 2 & 2 & . \\
\hline Echinophora spinosa & + & + & . & . & + & + & . \\
\hline Medicago marina & 3 & 2 & . & + & . & . & . \\
\hline Elytrigia juncea & . & . & . & + & + & + & . \\
\hline Eryngium maritimum & + & . & . & . & 1 & . & + \\
\hline Calystegia soldanella & . & . & . & . & . & . & . \\
\hline Euphorbia terracina & . & . & . & . & . & 2 & + \\
\hline \multicolumn{8}{|l|}{ Other species } \\
\hline Crepis foetida & 1 & + & . & 1 & 1 & + & + \\
\hline Anisantha sterilis & . & . & . & 1 & . & + & 3 \\
\hline Erigeron annuus & . & + & . & . & + & + & . \\
\hline Chondrilla juncea & . & . & . & 1 & . & + & + \\
\hline Phleum arenarium & . & . & . & 1 & . & . & . \\
\hline Xanthium orientale ssp. italicum & . & . & . & $\mathrm{r}$ & . & . & . \\
\hline Dasypyrum villosum & . & . & . & . & + & . & 1 \\
\hline Silene conica & . & . & + & . & 1 & . & . \\
\hline Verbascum sinuatum & . & . & . & . & . & + & + \\
\hline Petrorhagia saxifraga & . & . & . & . & . & + & 1 \\
\hline Oenothera sp. & + & 2 & . & . & . & . & . \\
\hline
\end{tabular}

\section{Other species:}

Pseudorlaya pumila 1: +; Linum trigynum 1: +; Euphorbia sp. 2: 1; Anagallis arvensis 2: +; Linum bienne 3: +; Plantago lanceolata 3: r; Cutandia maritima 3: r; Avena barbata 4: +; Cynodon dactylon 7: +; Imperata cylindrica 7: +; Carthamus lanatus 7: +; Tragopogon porrifolius 7: +; Plantago bellardii 7: +; Scirpoides holoschoenus 7: +; Oenothera biennis agg. 
Two dwarf cyperaceous communities developed on small surfaces are Cyperetum flavescentis and Cypero-Paspaletum distichi. They are found on wet, often flooded soils. Two Paspalum species dominate the stands; they are often trampled and their occurrence could be anthropogenic.

Moisture, salinity and nutrients are the most important ecological factors influencing the vegetation composition and spatial distribution of sand dunes (Fig. 5). These variables are also correlated to the first axis and salinity is correlated to the second axis of the NMDS plot. On the left side of the ordination diagram vegetation types of marshes and swamps in the centre are periodically flooded communities and on the right side communities of sand dunes are grouped. The centroid of group 2 (Limonio-Juncetum gerardii) is ecologically very similar to Isoëto-Nanojuncetea communities.

Plant communities identified on Velika plaža can be translated into eight habitat types according to Habitat directive (Tab. 4 ).

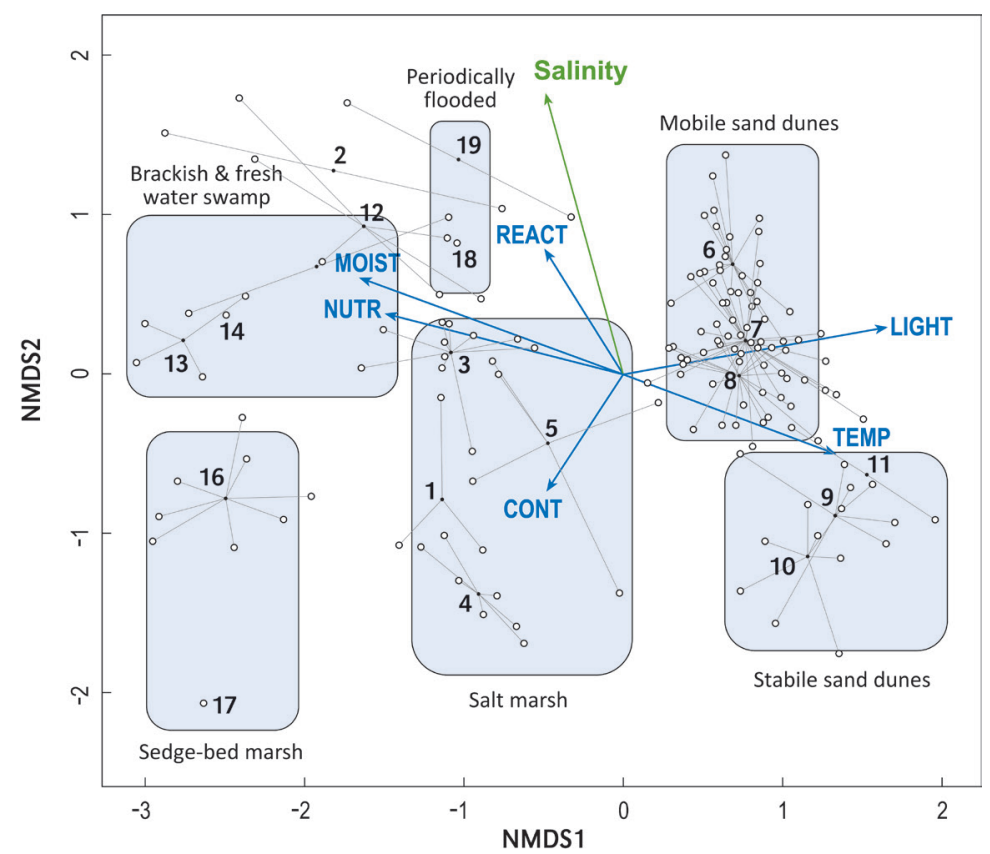

Fig. 5. Non-metric multidimensional scaling (NMDS) ordination spider-plot of the vegetation of Velika plaža. Numbers refer to centroids of vegetation types and dots represent relevés linked to the corresponding centroid (Tab. 1). Ecological indicator values are represented as arrows (MOIST-moisture, REACT-soil reaction, LIGHT-light, NUTR-nutrients, CONT-continentallity, TEMP-temperature). Plant communities found in similar site conditions are outlined. Stress value in two dimensions was 0.12 .

Tab. 4. Classification of syntaxa (plant associations) on Velika plaža into Habitat Directive habitat types (European Communities Council 1992).

\begin{tabular}{|c|c|c|c|}
\hline & Marceno et al. 2018 & $\begin{array}{l}\text { NATURA } 2000 \text { habitat type } \\
\text { (Annex I 92/43/EEC) }\end{array}$ & Syntaxa \\
\hline Zone without vegetation & $\begin{array}{l}\text { Zone without } \\
\text { vegetation }\end{array}$ & $\begin{array}{l}\text { Mudflats and sandflats not covered by } \\
\text { seawater at low tide } 1140\end{array}$ & \\
\hline $\begin{array}{l}\begin{array}{l}\text { Deposition zone } \\
\text { (drift line zone) }\end{array} \\
\end{array}$ & Strand line & Annual vegetation of drift lines 1210 & Cakilo-Xanthietum strumarii \\
\hline Embryonic dune & Embryonic dune & Embryonic shifting dunes 2110 & Euphorbio paraliae-Agropyretum junceiformis \\
\hline \multirow[t]{3}{*}{ White dune } & Foredune & $\begin{array}{l}\text { Shifting dunes along the shoreline with } \\
\text { Ammophila arenaria } 2120\end{array}$ & Medicagini marinae-Ammophiletum australis \\
\hline & \multirow[t]{2}{*}{ Fixed dune } & Dunes with Euphorbia terracina 2220 & Euphorbia terracinae-Silenetum nicaeensis \\
\hline & & Malcolmietalia dune grasslands 2230 & Onobrychido-Vulpietum fasciculatae \\
\hline \multirow[t]{2}{*}{ Dune slack } & \multirow[t]{2}{*}{ Dune slack } & $\begin{array}{l}\text { Mediterranean salt meadows } \\
\text { (Juncetalia maritimae) } 1410\end{array}$ & $\begin{array}{l}\text { Juncetum maritimo-acuti } \\
\text { Cuscuto cesatianae-Phyletum nodiflorae } \\
\text { Limonio narbonensis-Juncetum gerardii } \\
\text { Scirpetum maritimo-litoralis } \\
\text { Phragmitetum communis } \\
\text { Typhetum angustifoliae } \\
\text { Scirpetum lacustris } \\
\text { Cladietum marisci }\end{array}$ \\
\hline & & Humid dune slacks 2190 & $\begin{array}{l}\text { Eriantho-Schoenetum nigricantis } \\
\text { Cyperetum flavescentis } \\
\text { Cypero-Paspaletum distichi } \\
\text { Cyperetum longi } \\
\text { Holoschoenetum romani }\end{array}$ \\
\hline
\end{tabular}




\section{Discussion}

The vegetation of the sandy beach Velika plaža is very diverse in vegetation types and many of them have not previously been recorded there or anywhere else in Montenegro. The transitional geographic position of Velika plaža between the Adriatic and Ionian seas makes clear syntaxonomic classification of the plant communities of sand dunes difficult.

The vegetation of Velika plaža was frequently studied since the first mentions by Blečić and Lakušić (1976). Trinajstić (1989a) recorded the association Sporobolo-Elymetum farcti and later Mijović (Mijović 1994, Mijović et al. 2006, 2012) studied the zonation of sand dune vegetation, but mentioning only Cakilo-Xanthietum italici and Echinophoro-Elymetum farcti (=Agropyretum mediterraneum). All these authors identified only two plant communities: one on the drift line and the second on the dunes, without dividing it into different associations based on zonation and the stability of the dunes (Doing 1985, Marcenò et al. 2018). The dunes at Velika plaža are still well developed and the ideal zonation of dunes is still recognizable (Fig. 4) although human impact is present (Šilc et al. 2016a). We have confirmed several marsh and swamp associations, which have already been reported for Ulcinj and Montenegro in general but without relevé material (Blečić and Lakušić 1976). Additionally, Horvatić (1963) reported the presence of Euphorbio paraliae-Agropyretum for Budva-Sutoran area in Montenegro, which does not exist anymore.

Certain similarities can be found with the results of the vegetation study of the Buna River Protected Landscape in Albania (Fanelli et al. 2015), which is a natural continuation of Velika plaža to the south. However, in the sand dune vegetation on Velipoje beach today only drift line vegetation is present. The reasons are mainly erosion, but also the fast tourism development and intensive human impact on coastal areas in Albania. Still in the mid-1980s Mullaj (1989) found complete zonation on the sand dunes of Velipoje with Cakilo-Xanthietum italici, Agropyretum mediterraneum, Ammophiletum arundinaceae and Sporoboletum.

In Croatia sand dunes can be found fragmentarily in a few places with more or less depauperated plant composition of typical sand dune associations (Horvatić 1963, Trinajstić 1989b, Trinajstić and Jasprica 1998, Šilc et al. 2016b). Horvatić (1963) reports Agropyretum mediterraneum, Euphorbio-Glaucietum petrosum, and also Cyperetum flavescentis and Cypero-Paspaletum distichi.

On the Velika plaža we described a new plant association Cuscuto cesatianae-Phyletum nodiflorae. The species Phyla nodiflora (=Lippia $n$.) was first recorded for ex-Yugoslavia in Port-Milena channel, near Ulcinj (Bajić 1963). In the literature Ph. nodiflora occurs in four associations as a diagnostic species: Lippio nodiflorae-Panicetum repentis $\mathrm{O}$. de Bolòs 1957, Lippio nodiflorae-Paspaletum vaginati Galán De Mera et al. 2009, Fimbrystylo cymosae-Lippietum nodiflorae de Foucault 1987 and Kyllingo peruvianae-Phyletum nodiflorae Vanden Berghen 1990 (de Foucault 1987, Vanden Berghen 1990). Only the first is present in Europe, while the others are typical for Peru, Guadalupe and Senegal, respectively. The association from Velika plaža is very similar to Lippio nodiflorae-Panicetum repentis, especially to stands from Sicily (Brullo and Sciandrello 2006), where Ph. nodiflora is a co-dominant species, while in Spain these are short, dense grass carpets of Panicum repens sometimes even without Ph. nodiflora (Royo Pla 2006). Syntaxonomical classification of Lippio-Panicetum varies among different authors. De Bolòs (1957) originally classified it into the alliance Trifolio fragiferi-Cynodontion dactyli, and the classification is followed by Royo Pla (2006) and Ninot et al. (2012). Brullo and Sciandrello (2006) classified it into Paspalo-Agrostion semiverticillati of the class Molinio-Arrhenatheretea. Mucina et al. (2016) classified the alliance into Bidentetea tripartitae.

Taking into account the ecological features of the habitat of the new association Cuscuto cesatianae-Phyletum nodiflorae and its floristic structure and composition, we classify it into the alliance Juncion maritimi, order Juncetalia maritimi, and the class Juncetea maritimi.

In the hinterland of Velika plaža, the species Ph. nodiflora thrives within stands of Juncus maritimus. Such a community is also reported for the Viluni lagoon in Albania in the vicinity of Velika plaža. It develops in retrodunal depressions characterized by brackish water and strong disturbance by erosion and grazing by cattle (Fanelli et al. 2015). Due to the presence of similar habitats along the Albanian coast, it is expected that the association Cuscuto cesatianae-Phyletum nodiflorae will have a wider and more southwards distribution, although the species is not mentioned in the coastal flora of Albania or in the list of Albanian plant communities (Mullaj 1989, Dring et al. 2002).

Classification of the newly described association Onobrychido-Vulpietum ass. nova into higher syntaxa presents a particular challenge. Stands show a floristic composition distinct from other plant communities in the zonation and a description of a new association is therefore justified. There are no literature references of a similar plant community from neighbouring Croatia or Albania (Šilc et al. 2016b). There are two similar associations reported from Italy: Onobrychido caput-galli-Malcolmietum ramosissimae Brullo, Scelsi et Spampinato 2001 and Silene nicaeensis-Vulpietum fasciculatae (Paradis and Piazza 1991) Géhu et Biondi 1994, but their floristic composition is different and characteristic species are not present in Velika plaža (Díez-Garretas et al. 2003).

Therophytic stands on semi-stabilised sand dunes in Europe are classified into different alliances in addition to the different synsystems present. Mucina et al. (2016) introduced two ephemeral therophytic orders on sand dunes of the class Helianthemetea guttati: Vulpietalia under salt-spray influence and Malcolmietalia without it. Within the first one three alliances from the Balkan Peninsula area are classified: Psammo-Vulpion from the North Adriatic coasts, Vulpio-Lotion along Balkan-Illyric coast and Maresion nanae on North Aegean sand dunes. Inclusion of the newly described association into Vulpio-Lotion would be geographically most eligible but stands lack many characteristic species, mainly of the genus Trifolium (Horvat et al. 1974). In fact, typical Vul- 
pio-Lotion therophytic grasslands are found in the hinterland of Velika plaža and are not under the influence of saltspray. In Montenegro in general grasslands of Vulpio-Lotion are developed mainly on inland lowlands and not on the sand dunes (pers. obser.).

A different classification was previously presented by Biondi et al. (2014) for Italy including two orders within the Helianthemetea guttati on sand dunes. Cutandietalia (a synonym for Vulpietalia) comprises two alliances Alkanno-Maresion nanae and Laguro-Vulpion. The main difference between these alliances is in the disturbance of sand dunes (Brullo et al. 2001). The latter includes annual, xerophytic, pioneer communities of Mediterranean and thermo-Atlantic dunes in an early state of alteration owing to both natural and anthropic causes. Characteristic species (Vulpia fasciculata, Lagurus ovatus) are also present in the stands of Onobrychido-Vulpietum, also under constant anthropogenic pressure, which corresponds to the alliance description. According to some authors, Alkanno-Maresion nanae and Laguro-Vulpion could be merged together with some additional alliances due to a lack of differential species, which would yield one alliance, spanning the whole northern Mediterranean coast (Díez-Garretas et al. 2003). On the other hand the alliance Laguro-Vulpion fasciculatae was put into the Chenopodietea class by Mucina et al. (2016) indicating anthropogenic influence. In our opinion Onobrychido-Vulpietum should be classified into the alliance Laguro-Vulpion as an additional part of the Vulpietalia order.

We classified the stands dominated by Euphorbia terracina into the existing association Euphorbio-Silenetum nicaeensis, described from Greece. It is found on more stabilised dunes (Lavrentiades 1964) and was classified into the Crucianellion maritimae alliance (Sýkora et al. 2003). Two out of three characteristic species according to Lavrentiades (1964) are present (Euphorbia terracina and Hedypnois cretica), but we are of the opinion that these stands should also be classified into the therophytic alliance Laguro-Vulpion instead of the chamaephyte-dominated alliance Crucianellion. The floristic similarity of Euphorbio-Silenetum nicaeensis and Onobrychido-Vulpietum is well supported by the dendrogram (Fig. 2) and ordination (Fig. 5).

Classification of Paspalum distichum (=P. paspalodes) dominated stands is dubious. At Velipoje they are classified as Paspalo-Agrostidetum Br.-Bl. 1936 (1952) (Fanelli et al. 2015) but in nearby Bosnia and Herzegovina (Hutovo blato) as Cypero-Paspaletum distichi Horvat 1954 (Jasprica et al. 2003). These communities are classified in different classes, Molinio-Arrhenatheretea and Isoëto-Nanojuncetea, respectively. Our stands fit better into the latter class with characteristic ephemeral, annual vegetation of flooded sites, although they are fragmentarily developed, and with many character and differential species (Veronica anagalloides, Lotus tenuis, Bidens tripartitus, Inula britannica, Persicaria lapathifolia) missing.

Fanelli et al. (2015) classified the association Eriantho-Schoenetum nigricantis into the class Molinio-Arrhenatheretea, but we are of the opinion that it should be classified into the alliance Imperato cylindricae-Saccharion ravennae and in the class Phragmito-Magnocaricetea, as suggested by Mucina et al. (2016).

Association Holoschoenetum romani was traditionally classified into Molinio-Holoschoenion (Molinio-Arrhenatheretea), but recently Mucina et al. (2016) described this alliance as seasonally flooded meadows on subsaline soils of the Western Mediterranean. On the other hand, Biondi et al. (2014) list the alliance Agrostio stoloniferae-Scirpoidion holoschoeni (a synonym of Molinio-Holoschoenion) for Italy. We are the opinion that this community should be classified into the Juncetea class.

Limonio narbonensis-Juncetum gerardii is traditionally classified into Juncion maritimae alliance (Juncetea mariti$m i)$, but in our case it shows high floristic similarity with the class Isoëto-Nanojuncetea (Fig. 5).

Cyperus longus appears as the dominant species in two communities: Sparganio-Cyperetum longi Horvatić 1939 and Cyperetum longi Micevski 1957 (Hadžiablahović 2018). The latter is found on Velika plaža in depressions, usually in contact with Holoschoenetum vulgaris stands (Landucci et al. 2013).

Although habitat types occurring on Velika plaža have already been reported (Petrović et al. 2012) we can now list them with the corresponding species composition. It should be pointed out that some of the plant communities were sampled for the first time on this beach. For protection of the sand dune system a prerequisite is to have a survey of plant communities and their translation into habitat typology (Tab. 3). Some of the listed habitats, however, should be translated into new types in the future: Dunes along the Mediterranean shoreline with Ammophila arenaria (new code 2280) and Mediterranean embryonic dunes (new code 2290) as proposed by Feola et al. (2011).

In the first report of habitat types in Montenegro Cakilo-Xanthietum strumarii was classified into habitat type 2110 (Petrović et al. 2012), but it should be distinguished as a particular habitat type, Annual vegetation of drift lines 1210. Habitat type 2220 with Euphorbia terracina was placed separately but our analysis shows high floristic similarity with Onobrychido-Vulpietum fasciculatae (habitat type 2230) and an analysis on a larger scale is needed to confirm the existence of this habitat type on Velika plaža. The most stable dunes were previously classified into Fixed coastal dunes with herbaceous vegetation (grey dunes) $\left(2130^{\star}\right)$, but they should be now translated into Malcolmietalia dune grasslands (2230) (Biondi et al. 2012, Petrović et al. 2012, Prisco et al. 2012). A plant community with Euphorbia terracina was not confirmed in a previous survey of sand dune vegetation along the Eastern Adriatic (Šilc et al. 2016b).

Our results confirm for the first time the presence of plant communities of Laguro-Vulpion (and corresponding habitat types) along the north-eastern Adriatic coast and additional survey of such sand dunes is needed particularly in Albania to record any further stands to get a more comprehensive view on the vegetation type in the area. Transitional sand dune habitats (e.g. 2230 and 2210) are those with the highest 
diversity of phytosociological associations (Prisco et al. 2012).

Important habitat types that are present on Velika plaža but not sampled in our study are $2270^{\star}$ Wooded dunes with Pinus pinea and/or Pinus pinaster and 91E0* Alluvial forests with Alnus glutinosa and Fraxinus excelsior (Alno-Padion, Alnion incanae, Salicion albae). Although pine forests in Velika plaža are planted they are an important habitat type and may maintain the "valuable" Mediterranean coastal biodiversity pool (Bonari et al. 2017). Riparian forests are under-researched in south-eastern Europe (Douda et al. 2016) and many of them have already been destroyed in the vicinity in Albania (Kárpáti and Kárpáti 1961). There is a potential

\section{References}

Bajić, D., 1963: Species L. nodiflora Rich new to flora of Yugoslavia. Radovi Poljoprivrednog Fakulteta Univerziteta u Sarajevu 12, 209-211 (in Bosnian).

Biondi, E., Blasi, C., Allegrezza, M., Anzellotti, I., Azzella, M.M., Carli, E., Casavecchia, S., Copiz, R., Del Vico, E., Facioni, L., Galdenzi, D., Gasparri, R., Lasen, C., Pesaresi, S., Poldini, L., Sburlino, G., Taffetani, F., Vagge, I., Zitti, S., Zivkovic, L., 2014: Plant communities of Italy: The Vegetation Prodrome. Plant Biosystems 148, 728-814.

Biondi, E., Burrascano, S., Casavecchia, S., Copiz, R., Del Vico, E., Galdenzi, D., Gigante, D., Lasen, C., Spampinato, G., Venanzoni, R., Zivkovic, L., Blasi, C., 2012: Diagnosis and syntaxonomic interpretation of Annex I Habitats (Dir. 92/43/EEC) in Italy at the alliance level. Plant Sociology 49, 5-37.

Blečić, V., Lakušić, R., 1976: List of plant communities of Montenegro. Glasnik Republičkog Zavoda za Zaštitu Prirode i Prirodnjačkog Muzeja u Titogradu 9, 57-98 (in Montenegrin).

Bonari, G., Acosta, A.T., Angiolini, C., 2017: Mediterranean coastal pine forest stands: Understorey distinctiveness or not? Forest Ecology and Management 391, 19-28.

Braun-Blanquet, J., 1964: Pflanzensoziologie. Grundzüge der Vegetationskunde. Springer Verlag, Wien.

Brown, A.C., McLachlan, A., 2002: Sandy shore ecosystems and the threats facing them: some predictions for the year 2025 . Environmental Conservation 29, 62-77.

Brullo, S., Giusso Del Galdo, G.P., Siracusa, G., Spampinato, G., 2001: Considerazioni fitogeografiche sulla vegetazione psammofila dei litorali italiani. Biogeographia 22, 93-137.

Brullo, S., Sciandrello, S., 2006: La vegetazione lacustre del Biviere di Gela (Sicilia meridionale). Fitosociologia 42, 21-40.

Bubanja, N., 2016: Geobotanical characterization of vascular flora of Long Ulcinj beach and its hinterland in Montenegro. PhD thesis. University of Belgrade, Beograd (in Montenegrin).

Bubanja, N., Šinžar-Sekulić, J., Stevanović, V., 2019: Contribution to the flora of Velika plaža and its vicinity in Ulcinj (Montenegro). Biologia Serbica 41, 13-44.

Chytrý, M., Tichý, L., Holt, J., Botta-Dukat, Z., 2002: Determination of diagnostic species with statistical fidelity measures. Journal of Vegetation Science 13, 79-90.

de Bolòs, O., 1957: De vegetatione valentina. I. Collectanea Botanica. 5, 527-596.

De Foucault, B., 1987: Contribution a l'etude phytosociologique des paysages de Guadeloupe (Antilles françaises): la vegetation des plages et des falaises littorales. Phytocoenologia 15, 397-418.

Díez-Garretas, B., Asensi, A., Gavilán, R., 2003: Sabulicolous therophytic plant communities in the Mediterranean Region: a for the existence of habitat type 2240 Brachypodietalia dune grasslands with annuals, which might be confirmed in the further vegetation sampling.

\section{Acknowledgement}

The research (D.S., U.Š, F.K.) was partly financed through the Rufford project (14048-1), programme P1-0236 (ARRS), and bilateral grant (BI-ME/16-17-018). D.M. acknowledges support by Daphne - Inštitút aplikovanej ekológie. Authors are grateful to Mihailo Jovičević and Danka Petrović for help during field work and discussions.

proposal of phytosociological synthesis. Phytocoenologia 33, 495-526.

Doing, H., 1985: Coastal fore-dune zonation and succession in various parts of the World. Vegetatio 61, 65-75.

Douda, J., Boublík, K., Slezák, M., Biurrun, I., Nociar, J., Havrdová, A., Doudová, J., Aćić, S., Brisse, H., Brunet, J., Chytrý, M., Claessens, H., Csiky, J., Didukh, Y., Dimopoulos, P., Dullinger, S., FitzPatrick, Ú., Guisan, A., Horchler, P.J., Hrivnák, R., Jandt, U., Kącki, Z., Kevey, B., Landucci, F., Lecomte, H., Lenoir, J., Paal, J., Paternoster, D., Pauli, H., Pielech, R., Rodwell, J.S., Roelandt, B., Svenning, J.-C., Šibík, J., Šilc, U., Škvorc, Ž., Tsiripidis, I., Tzonev, R.T., Wohlgemuth, T., Zimmermann, N.E., 2016: Vegetation classification and biogeography of European floodplain forests and alder carrs. Applied Vegetation Science 19, 147-163.

Dring, J., Hoda, P., Mersinllari, M., Mullaj, A., Pignatti, S., Rodwell, J., 2002: Plant communities of Albania - a preliminary review. Annali di Botanica Nuova Serie 2, 7-30.

Euro+Med, 2006: Euro+Med PlantBase - the information resource for Euro-Mediterranean plant diversity. Retreived April 2, 2016 from http://ww2.bgbm.org/EuroPlusMed/

European Communities Council 1992: Council Directive 92/43/ CEE on the Conservation of Natural Habitats and of Wild Fauna and Flora. Official Journal L 206, 22/07/1992 P. 0007 $-0050$.

Fanelli, G., De Sanctis, M., Gjeta, E., Mullaj, A., Attore, F., 2015: The vegetation of the Buna river protected landscape (Albania). Hacquetia 14, 129-174.

Feola, S., Carranza, M.L., Schaminée, J.H.J., Janssen, J.A.M., Acosta, A.T.R., 2011: EU habitats of interest: an insight into Atlantic and Mediterranean beach and foredunes. Biodiversity and Conservation 20, 1457-1468.

Hadžiablahović, S., 2018: The diversity of the flora and vegetation of Lake Skadar/Shkodra. In: Pešić, V., Karaman, G., Kostianoy, A.G. (eds.), The Skadar/Shkodra Lake Environment, 203-238. Springer, Cham.

Hennekens, S.M., Schaminée, J.H.J., 2001: TURBOVEG, a comprehensive data base management system for vegetation data. Journal of Vegetation Science 12, 589-591.

Horvat, I., Glavač, V., Ellenberg, H., 1974: Vegetation Südosteuropas. Gustav Fischer Verlag, Stuttgart.

Horvatić, S., 1963: Vegetation map of island Pag with general overview of vegetation units of Croatian coast. Prirodoslovna Istraživanja, Jugoslavenska Akademija znanosti i umjetnosti 33, 1-187 (in Croatian).

Janssen, J.A.M., Rodwell, J.S., Criado, M.G., Gubbay, S., Haynes, T., Nieto, A., Sanders, N., Landucci, F., Loidi, J., Ssymank, A., 
Tahvanainen, T., Valderrabano, M., Acosta, A., Aronsson, M., Arts, G., Attorre, F., Bergmeier, E., Bijlsma, R.-J., Bioret, F., Biţă-Nicolae, C., Biurrun, I., Calix, M., Capelo, J., Čarni, A., Chytrý, M., Dengler, J., Dimopoulos, P., Essl, F., Gardfjell, H., Gigante, D., Giusso del Galdo, G., Hájek, M., Jansen, F., Jansen, J., Kapfer, J., Mickolajczak, A., Molina, J.A., Molnár, Z., Paternoster, D., Piernik, A., Poulin, B., Renaux, B., Schaminée, J.H.J., Šumberová, K., Toivonen, H., Tonteri, T., Tsiripidis, I., Tzonev, R., Valachovič, M., 2016: European red list of habitats. 2. Terrestrial and freshwater habitats. Publications Office of the European Union, Luxembourg.

Jasprica, N., Carić, M., Batistić, M., 2003: The marshland vegetation (Phragmito-Magnocaricetea, Isoëto-Nanojuncetea) and hydrology in the Hutovo Blato Natural Park (Neretva River delta, Bosnia and Herzegovina). Phyton, Annales Rei Botanicae, Horn 43, 281-294.

Kárpáti, I., Kárpáti, V., 1961: Die zönologischen verhältnisse der Auenwälder Albaniens. Acta Botanica Academiae Scientarum Hungarica 7, 235-301.

Landucci, F., Gigante, D., Venanzoni, R., Chytrý, M., 2013: Wetland vegetation of the class Phragmito-Magno-Caricetea in central Italy. Phytocoenologia 43, 6-102.

Lavrentiades, G.J., 1964: The ammophilous vegetation of the Western Peloponnesos coasts. Vegetatio 12, 223-287.

Marcenò, C., Guarino, R., Loidi, J., Herrera, M., Isermann, M., Knollová, I., Tichý, L., Tzonev, R.T., Acosta, A.T.R., FitzPatrick, Ú., Iakushenko, D., Janssen, J.A.M., Jiménez-Alfaro, B., Kącki, Z., Keizer-Sedláková, I., Kolomiychuk, V., Rodwell, J.S., Schaminée, J.H.J., Šilc, U., Chytrý, M., 2018: Classification of European and Mediterranean coastal dune vegetation. Applied Vegetation Science 21, 533-559.

Maun, M.A., 2009: The biology of coastal sand dunes. Oxford University Press, New York.

Mijović, A., 1994: The xerohalophytic sand communities of the Long beach. Glasnik Instituta za Botaniku i Botaničke Bašte Univerziteta u Beogradu 28, 147-157.

Mijović, A., Popović, Z., Karadžić, B., Mijatović, M., Perišić, S., 2006: Distribution of xerohalophytic vegetation along the seaward and landward zone in south-Adriatic sandy beach (Montenegro). Biotechnology \& Biotechnological Equipment 20, 30-35.

Mijović, A., Popović, Z., Vukov, T., Smiljanić, M., Matić, R., Bojović, S., 2012: Sand topography influences the distribution of xerohalophytic vegetation on a southern Adriatic beach in Montenegro. Plant Biosystems 146, 664-673.

Mucina, L., Bültman, H., Dierssen, K., Theurillat, J.-P., Dengler, J., Čarni, A., Šumberová, K., Raus, T., Di Pietro, R., Gavilán Garcia, R., Chytrý, M., Iakushenko, D., Schaminée, J.H.J., Bergmeier, E., Santos Guerra, A., Daniëls, F.J.A., Ermakov, N., Valachovič, M., Pigantti, S., Rodwell, J.S., Pallas, J., Capelo, J., Weber, H.E., Lysenko, T., Solomeshch, A., Dimopoulos, P., Aguiar, C., Freitag, H., Hennekens, S.M., Tichý, L., 2016: Vegetation of Europe: Hierarchical floristic classification system of plant, lichen, and algal communities. Applied Vegetation Science 19, 3-264.

Mullaj, A., 1989: Albanian coastal vegetation. Albanian Academy of Sciences, Tirana (in Albanian).

Ninot, J.M., Font, X., Masalles, R.M., Vigo, J., 2012: Syntaxonomic conspectus of the vegetation of Catalonia and Andorra. II: Ruderal communities. Acta Botanica Barcinonensia 53, 113-189.

Petrović, D., Karaman, M. 2009: Important plant areas in Montenegro - IPA Programme. NVO Zelena Gora, Podgorica

Petrović, D., Hadžiablahović, S., Vuksanović, S., Mačić, V., Lakušić, D., 2012: Catalogue of habitat types of Monenegro important for European Union. Regional Environmental Center Montenegro, Podgorica-Beograd-Zagreb (in Montenegrin).

Pignatti, S., 1982: Flora d'Italia. Edagricole, Bologna.

Pignatti, S., Mengoni, P., Pietrosanti, S., 2005: Valori di bioindicazione delle piante vascolari della flora d'Italia. Braun-Blanquetia 39, 1-97.

Prisco, I., Acosta, A.T.R., Ercole, S., 2012: An overview of the Italian coastal dune EU habitats. Annali di Botanica (Roma) 2, 39-48.

R Development Core Team, 2012. R: A language and environment for statistical computing. Retrieved October 15, 2015 from http://www.r-project.org.

Royo Pla, F., 2006: Flora i vegetació de les planes i serres litorals compreses entre el riu Ebro i la serra d'Irta. University of Barcelona, Barcelona.

Šilc, U., Mullaj, A., Alegro, A., Ibraliu, A., Dajić Stevanović, Z., Luković, M., Stešević, D., 2016a: Sand dune vegetation along the eastern Adriatic coast. Phytocoenologia 46, 339-355.

Šilc, U., Dajić Stevanović, Z., Ibraliu, A., Luković, M., Stešević, D., 2016b: Human impact on sandy beach vegetation along the southeastern Adriatic coast. Biologia 71, 865-874.

Šilc, U., Caković, D., Küzmič, F., Stešević, D., 2017: Trampling impact on vegetation of embryonic and stabilised sand dunes in Montenegro. Journal of Coastal Conservation 21, 15-21.

Šilc, U., Küzmič, F., Caković, D., Stešević, D., 2018: Beach litter along various sand dune habitats in the southern Adriatic (E Mediterranean). Marine Pollution Bulletin 128, 353-360.

Šilc, U., Stešević, D., Rozman, A., Caković, D., Küzmič, F., 2019: Alien species and their impact on sand dunes in NE Adriatic. In: Finkl, C.W., Makowski, C. (eds.), Impacts of Invasive Species on Coastal Environments: Coasts in Crisis, 113-143. Springer, Cham.

Stešević, D., Luković, M., Caković, D., Ružić, N., Bubanja, N., Šilc, U., 2017a: Alien species in sand dune plant communities on Velika plaža in Ulcinj (Montenegro). Periodicum biologorum 119, 239-249.

Stešević, D., Bubanja, N., Caković, D., Jogan, N., Luković, M., Šilc, U., 2017b: Synecology of Cutandia maritima (L.) Barbey, a rare psammophytic species along the Montenegrin Coast (East Adriatic Coast). Hacquetia 16, 181-187.

Sýkora, K.V., Babalonas, D., Papastergiadou, E.S., 2003: Strandline and sand-dune vegetation of coasts of Greece and of some other Aegean countries. Phytocoenologia 33, 409-446.

Tichý, L., 2002: JUICE, software for vegetation classification. Journal of Vegetation Science 13, 451-453.

Tichý, L., Chytrý, M., 2006: Statistical determination of diagnostic species for site groups of unequal size. Journal of Vegetation Science 17, 809-818.

Trinajstić, I., 1989a: Contribution to knowledge of the sand dunes vegetation of the Ammophiletea class on Montenegro coast. Crnogorska Akdemija Nauka i umjetnosti, Glasnik Odjeljenja Prirodnih nauka 7, 45-51 (in Croatian).

Trinajstić, I., 1989b: Vegetation of the class Ammophiletea Br.-Bl. et R. Tx. 1943 in the eastern Adriatic littoral of Yugoslavia. Colloques Phytosociologiques 19, 387-394.

Trinajstić, I., Jasprica, N., 1998: Vegetation of the class Ammophiletea Br.-Bl. et R. Tx. in the southern part of the Croatian littoral (Dalmatia). Natura Croatica 7, 79-83.

van der Maarel, E., 2005: Vegetation ecology. Blackwell, Malden.

Vanden Berghen, C., 1990: La végétation des sables maritimes de Ia Casamance (Sénégal méridional). Lejeunia NS 133, $1-84$. 